JURNAL SENI MUSIK

\title{
THE EXISTENCE OF KENTHONGAN AS FOLK ART: STUDY OF KENTHONGAN BANYUMAS
}

\author{
Ibnu Amar Muchsin ${ }^{凶}$
}

Fakultas Bahasa dan Seni, Universitas Negeri Semarang, Indonesia

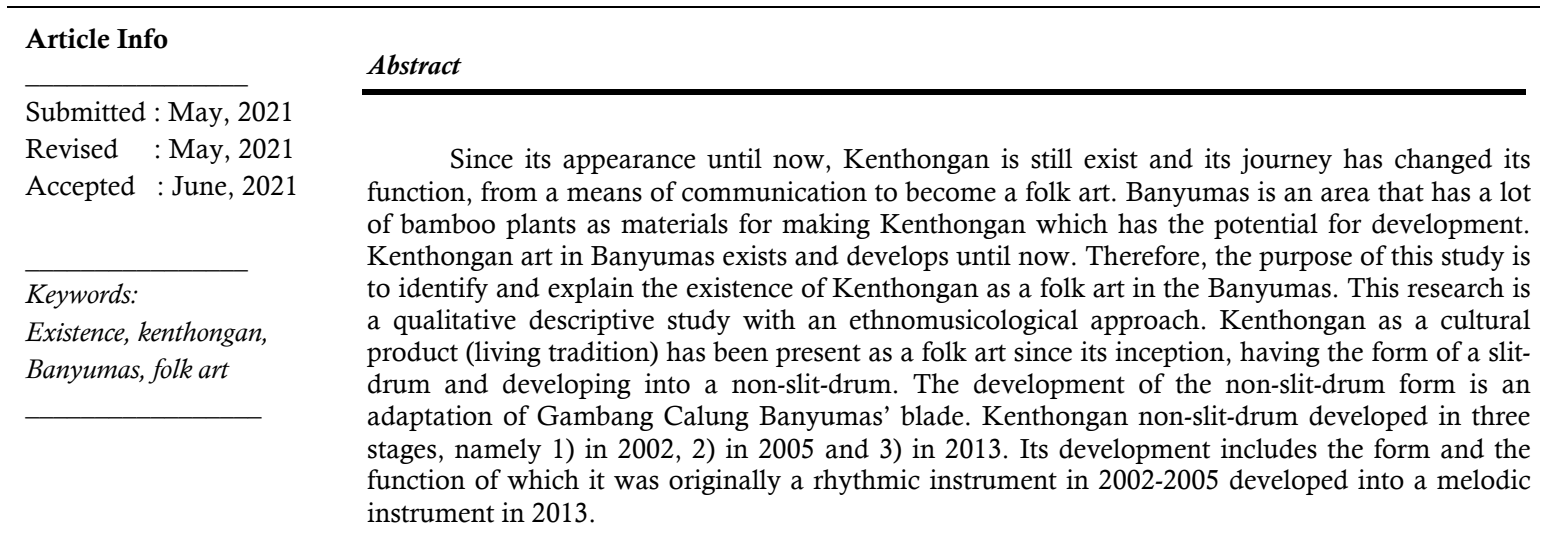




\section{INTRODUCTIONS}

Art is one of the most strategic elements of culture. Its main asset source is human intuition and imagination which is poured into the medium of sound, appearance, and motion (Koentjaraningrat, 2009). It grows and develops in a community tradition, becoming a traditional art. Its sustainability always passes from one generation to another until an identity is realized for the community.

Banyumas as an area that has a strategic position between two different cultural areas (Sunda and Java). The two cultures mutually push and give birth to various kinds of traditional arts and create a strong identity for Banyumas. Banyumas art has strong characteristics from two aspects of cultural elements, namely language and living equipment.

The geographical condition of Banyumas was a plain and mountainous area that cannot be separated from bamboo plants (bambuseae) which are a type of tropical bamboo plant. These plants grow a lot around rivers and mountains. Bamboo has always played an important role in human life. Bamboo is a multifunctional plant, starting from living utensils, food ingredients, and traditional instrument materials (Supanggah, 2002). Somawijaya explained that there are 18 uses and benefits of bamboo in people's lives. Two of them are as musical instruments: karinding, celempung, suling (flute), calung, gambang (xylophone), angklung; and related to public works ('communication facility'): Kenthongan (Somawijaya, 2016).

Bamboo had a meaning in ritual ceremonies where bamboo is used as a symbol of these activities such as: 1) seven months pregnant salvation, 2) cutting the baby's umbilical cord using a scythe, 3) tedak sinten ceremony in a chicken cage. 4) elekan taiang bamboo (marriage) and 5) as a rejection of yellow bamboo necklace reinforcements (Somawijaya, 2016).

There are 20 types of bamboo that exist and develop in Banyumas, but the type of bamboo that is most widely used is the type of wulung bamboo (black) named Latin Gigntochloa Atroviolacea. This bamboo is used as a material to make various necessities of human life, one of which is as a communication tool in ancient times that still exists today, namely Kenthongan.

Kenthongan was a communication tool made of bamboo or wood. The cultural history of
Kenthongan comes from the legend of $\mathrm{Ho}$ Chi Min from China who traveled on a religious mission. On the way, Cheng Ho found this Kenthongan as a tool of religious communication. The discovery of Kenthongan was brought to China, Korea and Japan.

Kenthongan has been found since the beginning of the century. Each region certainly has a different history of discovery with a high historical value. In the area of NTB, Kenthongan was found when King Anak Agung Gede Ngurah ruled around the XIX century and used it to gather masses. Meanwhile, during the Majapahit kingdom, Kenthongan Kyai Gorobangsa was often used as a community gathering tool (Moertjipto, 1990).

Kenthongan besides functioning as a communication tool in the community, it is also used as a marker of prayer times which is used as the pair of Bedug (drum) in the mosque. Kenthongan will be sounded first before followed by the sound of the Bedug (drum). However, along with today's developments, not many mosques still use Kenthongan and Bedug (drum) as a marker of prayer times before the call to prayer begins.

Kenthongan besides functioning as a communication tool in the community, it is also used as a marker of prayer times which is used as a drum pair in the mosque. Kenthongan will be sounded first before followed by the sound of the drum. However, along with today's developments, not many mosques still use Kenthongan and Bedug as a marker of prayer times before the call to prayer begins.

Kenthongan as a folk art in Banyumas has been existed since the 1980s, where Kenthongan functioned as a communication tool in the kampong security post and began to be used as a musical instrument. The musical ensemble used as night patrol music is a Kenthongan made with a certain rhythm pattern. Then in the 1980s, the Banyumas Regency government held an arts festival which featured performances from various sub-districts and most of the participants used Kenthongan in various actions.

Existence refers to the meaning of being about what exists, what has actualized, everything that is experienced and emphasized that something exists, and perfection (Lorens, 1996). The existence of Kenthongan as a folk art began to develop since the 1980s until now. Creativity and development continues to this day. The study of existence of Kenthongan as a folk art in 
Banyumas is interesting to study how Kenthongan runs and develops and continues to exist which was originally a means of communication until finally it became a product of folk art.

\section{METHODS}

This research is a qualitative research with an ethnomusicological approach to determine the existence of Kenthongan as a folk art in Kenthongan Banyumas. The main object of this research is Kenthongan as a folk art. The data presented are in the form of descriptions obtained by taking direct observations with Kenthongan art actors in Banyumas.

The collection of data sources used by researchers refers to Rohidi (2011), namely 4P: 1) Person (resource person). 2) Place (place), 3) Process (activities), and 4) Paper (documentation). The interviewees were Kenthongan Banyumas art performers and staff from the Banyumas district culture and tourism office. The place of this research was conducted in Banyumas Regency with a focus on several points of Kenthongan arts centers such as in Baturaden District, Ajibarang District, and Purwokerto District. The activities studied are Kenthongan art activities which are carried out routinely both from groups and from festival organizers.

Observations were carried out by observing directly and by conducting interviews with the informants to obtain the expected data. Furthermore, data analysis is carried out through a data reduction process that will produce conclusions.

\section{RESULTS AND DISCUSSION}

Banyumas is famous for its wide variety of bamboo music, all of which are part of the local folk music. Bamboo music was often played at agricultural ceremonies to summon rain, marking the start of the planting and harvesting seasons, as well as at family gatherings and in various events such as building inauguration, celebrations of major holidays, and artistic activities.

\footnotetext{
Kenthongan (some call Thek-thek), is a musical instrument made of bamboo (Bambuseae) or the Banyumas people call it pring. Banyumas is a mountainous area that has the potential for growing bamboo plants. On the outskirts of the Serayu River you can find a group of bamboo trees. The types of bamboo
}

that grow and develop in Banyumas include wulung bamboo, tali bamboo, and petung bamboo (Supanggah, 2002).

Kenthongan Banyumas art is an art that comes from a development of Kenthongan tools which originally functioned as a means of communication into an art. Kenthongan art has various terms, namely Kentongan, Thek-thek, and Themling. The existence of Kenthongan music in Banyumas cannot be separated from the changing trend of local people who live in the era of cultural transition.

This variety of artistic terminology creates various titles with different object names, but in fact the object is Kenthongan Banyumas art. Various terms to describe this art include: 1) Kenthongan (Khasanah, Uswatun; Yuwono, Pratik Hari; Irianto, 2020; Muchsin, 2017; Larasati, 2012) 2) Kentongan (Basuni, 2017; Hindarto, 2018; Prasetyo, 2018; Sasongko; \& Rachman, 2017; Sasongko \& Rachman, 2017) 3) Thek-thek (Pradana, 2017; Shah, 2013) 4) Thillung (Sari, 2013), 5) Rampak Kenthong (Prime, 2017). The research that has been done on Kenthongan Banyumas Arts examines the form of presentation/performance, function, creativity, development, meaning of contestation, aesthetic expression, and musical arrangement. Both in the Banyumas area (ExKarisidenan) and outside the region (Larasati, 2012; Muchsin, 2017; Perdana, 2017; Pradana, 2017; Prasetyo, 2018; Sari, 2013; Sasongko \& Rachman, 2017; Sumiyati, 1989; Shah, 2013).

The journey of Kenthongan art has gone through ups and downs since 1997. This art has existed. The peak of this artistic development was in 2004, where that year almost all RT (Rukun Tetangga) in Banyumas Regency had a Kenthongan Art group. (Muchsin, 2017) The Kenthongan Festival is regularly held every August. However, in 2020 this festival was canceled due to the outbreak of Covid-19 pandemic.

In terms of music, Kenthongan Art has completely fulfilled the musical elements of rhythm, melody and harmony (Budhidarma, 2001). These three elements exist and are present in Kenthongan art. However, in comparison, the number of rhythmic instruments used is more than that of melodic instruments (Prasetyo, 2018). Kenthongan Banyumas musical instruments consist of Kenthong, Angklung, Bamboo Flute, Ketrak (Tripok), Ketipung, Gentong Bass and tambourine (Muchsin, 2017). 
Kenthongan Banyumas art consists of two kinds, 1) Kenthongan as a performing art that has elements of music and dance; 2) Kenthongan as a musical performance only. As an art, Kenthongan is presented with a large number of players, such as a marching band performance with costumes and movements. While Kenthongan art is a musical performance with a limited number of players and does not use the order of dance movements and fancy costumes (Muchsin, 2017).

\section{Kenthongan progress from slit-drum to non- slit-drum}

Kenthongan Banyumas art had its roots in traditional arts that developed in the Banyumas Region. A strong traditional art that becomes the identity of Banyumas is the Calung Banyumasan Art (Syah, 2013). This art is made from bamboo which is the source of the birth of Kenthongan Banyumas. The term Kenthongan refers to a tool that has developed in Indonesian society that has a function as a communication tool (Larasati, 2012; Shah, 2013). This art is made from bamboo which is the trigger for the emergence of Kenthongan Banyumas (Larasati, 2012; Shah, 2013).

Kenthongan was elongated with an elongated cavity in the middle (slit drum), beaten with a bat on the edge of the cavity, and produces a resonant and strong sound (Sumiyati, 1989). Based on the sound source, this instrument is classified as an idiophone instrument. Idiophone instruments are a variety of musical instruments in which the body of the instrument itself is the source of the sound (Banoe, 2007).

Kenthongan was not something new when it was viewed as a tool. The novelty lies in the transition of its function, from an "ordinary" communication tool to a musical instrument, to being part of a musical ensemble. Kenthongan in a form of the Slit drum has been become a living tradition, an old performing art that is still alive today. A living tradition is the result of our old socio-cultural context, even though its form was incomplete anymore (Jaeni, 2011).

It was not clear when the Kenthongan changed from slit-drum to non-slit-drum. However, Sutar's statement in an interview in 2015 stated that the emergence of Kenthongan form creations has existed since the 2000s. The non-slit-drum form of Kenthongan is an adaptation of the xylophone blade in Banyumas art. The only difference is that the dimensions are bigger than the xylophone calung's piece.

Kenthongan non-slit-drums have evolved in form and function. According to Rustam in an interview in 2015 stated that the change in the shape of the Kenthongan occurred in three stages, they are 1) in 2002, 2) in 2005, and 3) in 2013. In 2002 and 2005 the non-slitdrum Kenthong instrument served as a rhythmic function. Then development in 2013 the Kenthong instrument served as a melodic instrument.

Kenthongan in 2002 had a characteristic that consists of two bamboo segments (two tones) that covers of notes 2 (ro) and 6 (nem) in Javanese Karawitan or 1 (do) and 5 (sol) in diatonic notation, which is shaped like a Calung xylophone from Banyumas.

The advantages of the form of Kenthongan in this era are very helpful for attractions in the presentation because in this era Kenthongan is presented in the form of performances. The weakness of this form of Kenthongan besides being large and heavy, it must be held in the player's stomach and there must be a rope to hold the Kenthongan which is worn around the player's neck, thus making it less comfortable when players used it. The performances of attractions in this era were identical to the Kenthong movement which swayed to the right and left.

The Kenthongan instrument design model in 2005 was no different from the previous one, which had two Kenthongan segments. However, its size is smaller and lighter, so it is more flexible to be played. The new instruments no longer have belly support and a neck strap. The new shapes are placed on the right and left of it. The wood in the middle serves as a lever.

The notation/segment pattern of Kenthongan's playing in 2005 was not much different from the previous, because there were only two notes, namely 'tung' and 'dung'. However, a more flexible form makes this Kenthongan not only function as a musical instrument but can be used as property during dance performances. The size of the Kenthongan in 2005 was slimmer and smaller, with a bamboo segment length of $80 \mathrm{~cm}$ and a diameter of $6.5 \mathrm{~cm}$.

The Kenthongan instrument which originally consisted of only two bamboo 
segments and only functions as a rhythmic with repeated playing pattern (ostinato), 2013 has been changed to a pitched Kenthongan instrument. Sutar, a man born in Rempoah, Baturaden sub-district, Banyumas Regency, is a figure who has the initial idea of making a pitched Kenthongan instrument. This is inspired by the Xylophone musical instrument in the art of Calung Banyumasan.

The form of this pitched Kenthongan instrument consists of several tones. The notes made are diatonic tones. The diatonic scale is a sequence of notes containing the unit distance (tones) and the middle of the barrel (semitones), there are two kinds of diatonic scales, the major diatonic scale (c-d-e-f-g-a-b-c) and the minor diatonic scale (a-b-c-d-e-f-g-a-b-c). There are 3 types of this instrument: (1) large-sized Kenthongan, (2) medium-sized Kenthongan, and (3) small-sized Kenthongan. Each size has a different number of notes and playing patterns.

Kenthongan in this era is no longer held directly but placed on ancak or a buffer made of bamboo. The function of the Kenthongan instrument is no longer used as a property for motion and song, but only as a musical instrument for performances on stage that do not move.

Kenthongan's non-slit-drum instruments since their appearance until now have all remained and developed in the ex-residential areas of Banyumas (Banyumas, Purbalingga, Banjarnegara, and Cilacap).

\section{CONCLUSION}

Kenthongan, as a folk art of Banyumas, still exists today and continues to grow in the Banyumas area. This art has become a living tradition even though the form of Kenthongan has changed in its form and function.

Kenthongan Banyumas has a variety of terminology and writing, such as Kenthongan , Kentongan, Thek-thek, Tek-tek, Kenthong, Rampak Kenthong, Thilung. The whole variety of terms does not change the essence and form of Kenthongan Banyumas' performances.

Kenthongan was originally a communication tool developed into a musical instrument and folk art. The form of the Kenthongan which was originally a slit-drum developed into a non-slit-drum which was adapted from the xylophone form in Calung Banyumas.
Kenthongan non-slit-drums developed and changed form and function through three stages: 1) in 2002, 2) in 2005 and 3) in 2013. All forms of development until now still exist and develop in the Banyumas area.

Kenthongan as a folk art will always develop not only in the Banyumas area but also outside Banyumas. Kenthongan Banyumas which has developed in areas outside Banyumas for a long period has allowed it to become an archipelago populist art that has developed throughout Indonesia.

\section{REFERENCES}

Banoe, P. (2007). Kamus Musik. Kanisius.

Basuni, B. (2017). Efektivitas dakwah Islam melalui Kolaborasi Seni Kenthongan dan Hadroh Banyumasan (Studi Komunitas Kenthosh, Rawalo - Banyumas). Jurnal Ilmiah Mahasiswa Raushan Fikr, 6(2), 145158.

https://doi.org/10.24090/jimrf.v6i2.2738

Budhidarma. (2001). Pengantar Komposisi dan Arransemen. Media Komputindo.

Hindarto, T. (2018). Kentongan Dan Simbol Status Sosial: Studi Kasus Di Wilayah Desa Paketingan Kecamatan Sampang Kabupaten Cilacap. Analisa Sosiologi, 7(2), 274-282.

Jaeni. (2011). Komuniasi Estetik: Menggagas Kajian Seni dari Peristiwa Komunikasi Pertunjukan. PT Penerbit IPB Press.

Khasanah, Uswatun; Yuwono, Pratik Hari; Irianto, S. (2020). Peran Ekstrakulikuler Kenthongan Dalam Menumbuhkan CInta Tanah Air Pada Siswa Mi Ma'arif NU Teluk. Jurnal Educatian and Development, 8(3), 21-25.

Koentjaraningrat. (2009). Pengantar Ilmu Antropologi. Rineka Cipta.

Larasati, T. A. (2012). Kesenian Tradisional Kenthongan Wahana Remaja dan Pemuda Purbalingga Mencintai Kesenian Rakyat. Jantra: Jurnal Sejarah Dan Budaya, VII(2), 153-161.

Lorens, B. (1996). Kamus Filsafat. Gramedia.

Moertjipto. (1990). Bentuk-bentuk Peralatan Hiburan dan Kesenian Tradisional 
Kawasan Istimewa Yogyakarta. Departemen Pendidikan dan Kebudayaan, Direktorat Jenderal Kebudayaan, Direktorat Sejarah dan Nilai Tradisional.

Muchsin, I. A. (2017). Kenthongan Banyumas: Kreativitas dan Perkembangannya. Universitas Gadjah Mada.

Perdana, F. (2017). Kesenian Rampak Kenthong sebagai Media Ekspresi Estetik Masyarakat Desa Kalirejo Kabupaten Pekalongan. Catharsis, 6(1), 1-8.

Pradana, B. F. (2017). Makna Kontestasi Kesenian Thek-thek di Kabupaten Purbalingga. Universitas Negeri Semarang.

Prasetyo, K. (2018). Kreativitas dan aransemen musik pada grup kentongan pudang satria di kabupaten banyumas. Jurnal Seni, 7(1).

Rohidi, T. R. (2011). Metodologi Penelitian Seni. CV Cipta Prima Nusantara Semarang.

Sari, Y. L. (2013). Fungsi dan Bentuk Penyajian Musik Thillung di Dagaran Jurug Sewon Bantul. Universitas Negeri Yogyakarta.
Sasongko; W. S., \& Rachman, A. (2017). Kreativitas musik pada grup kentongan adiyasa di kabupaten banyumas. Seni Musik Unnes.

Sasongko, W. S., \& Rachman, A. (2017). Kreativitas Musik pada Grup Kentongan Adiyasa di Kabupaten Banyumas. Seni Musik Unnes, 6(2), 66-80.

Somawijaya, A. (2016). Budaya Bambu Jawa Barat (S. Rustiyani (ed.)). Sunan Ambu Press.

Sumiyati, F. (1989). Makna Lambang dan Simbol Kentongan Dalam Masyarakat Indonesia.

Supanggah, R. (2002). Musik Bambu. In Indonesian Heritage jilid ke-8 Seni Pertunjukan (p. 34). Jayakarta Agung Offset.

Syah, fajry subhan. (2013). Kesenian Thek-Thek Walisongo Di Kelurahan Tritih Kulon Kecamatan Cilacap Utara Kabupaten Cilacap: Kajian Tekstual (Bentuk Pertunjukan Dan Komposisi Musikal). Jurnal Seni Musik, 2(2), 1-14. 